\title{
ADVERTISEMENT CALL OF Hyla jimi AND Hyla elianeae (ANURA, HYLIDAE) IN THE BOTUCATU REGION, SÃO PAULO, BRAZIL
}

\author{
MARTINS, I. A. ${ }^{1}$ and JIM, J. ${ }^{2}$ \\ ${ }^{1}$ Laboratório de Zoologia, Departamento de Biologia, Universidade de Taubaté, UNITAU, \\ CEP 12030-010, Taubaté, SP, Brazil \\ ${ }^{2}$ Departamento de Zoologia, Universidade Estadual Paulista, UNESP, Campus de Botucatu, \\ CEP 18618-000, Botucatu, SP, Brazil \\ Correspondence to: Itamar A. Martins, Laboratório de Zoologia, Departamento de Biologia, \\ Universidade de Taubaté, UNITAU, Pça. Marcelino Monteiro, 63, CEP 12030-010, \\ Taubaté, SP, Brazil, e-mail: istama@uol.com.br \\ Received March 24, 2003 - Accepted June 6, 2003 - Distributed August 31, 2004
}

(With 4 figures)

\begin{abstract}
In this work we present a description of the advertisement call of $H$. jimi, the locality type, and of $H$. elianeae, until now unknown in the literature. Field activities were carried out from August 1997 through June 1999; recordings were made in two open-area environments in the Botucatu region, São Paulo State. Vocalizations of 100 individuals ( $49 \mathrm{H}$. jimi and $51 \mathrm{H}$. elianeae) were recorded; nine characteristics of the advertisement call were examined. The advertisement calls of both species consist of consecutive series of simple notes with relatively fast repetition rates. Males of $H$. jimi and $H$. elianeae presented two patterns of note emission: one emitted by individuals beginning vocalization activity or isolated from the aggregate, and another emitted by males in chorus activity interacting with closely neighboring males. A significant difference was verified in the temporal structure of the two vocalization patterns.
\end{abstract}

Key words: vocalization, advertisement call, Hylidae, Hyla jimi, Hyla elianeae.

\section{RESUMO}

\section{Canto de anúncio de Hyla jimi e Hyla elianeae (Anura, Hylidae) na região de Botucatu, São Paulo, Brasil}

Neste trabalho apresenta-se a descrição do canto de anúncio de $H$. jimi, para a localidade tipo, e de H. elianeae, ainda desconhecida da literatura. As atividades de campo foram desenvolvidas de agosto de 1997 a junho de 1999. As gravações foram efetuadas em ambientes de área aberta na região de Botucatu, Estado de São Paulo. Foram registradas vocalizações de 100 exemplares, 49 de H. jimi e 51 de H. elianeae; foram analisadas nove características do canto de anúncio. O canto de anúncio de ambas as espécies consiste em uma série consecutiva de notas simples com taxa de repetição relativamente rápida. Machos de $H$. jimi e H. elianeae apresentaram dois padrões de emissão de notas. Um emitido por indivíduos iniciando a atividade de vocalização ou isolado do agregado e outro emitido por machos em atividade de coro, interagindo com machos vizinhos. Foram verificadas diferenças significativas na estrutura temporal nos dois padrões de vocalizações.

Palavras-chave: vocalização, canto de anúncio, Hylidae, Hyla jimi, Hyla elianeae.

\section{INTRODUCTION}

Advertisement calls (sensu Wells, 1977) contain spectral and temporal information relevant to specific recognition (Salthe \& Mecham, 1974; Wells, 1977, 1988; Ryan, 1985; Ryan, 2001). Besides having several roles in social organization, such as recruiting individuals to choruses, attracting sexual 
mates (acting as efficient reproductive isolating mechanisms), functioning in territorial behavior, and promoting spacing of males, these calls represent adaptations that avoid or reduce intra- or interspecific acoustic interference (Wells, 1988; Schwartz \& Wells, 1983, 1984 a; Bastos \& Haddad, 1995; Grafe, 1996; Given, 1999).

In taxonomic and systematic studies, the acoustic characteristics of anurans have been exhaustively used as important characters in specific diagnosis, for species description, or for verification of phylogenetic relationships among groups of species (Márquez et al., 1993; Pombal et al., 1995; Garcia et al., 2001; Rossa-Feres \& Jim, 2001; Hartmann et al., 2002).

Advertisement calls of anurans are excellent behavioral traits in comparative studies (Ryan, 2001). Calls of sympatric species may be very similar except for certain traits such as temporal parameters (Passmore, 1981). Comparative studies of advertisement calls based on quantitative and qualitative parameters may provide relevant information for problem-solving (Márquez et al., 1993), especially those arising in dealing with closely related taxonomic groups.

Hyla jimi, described by Napoli \& Caramaschi (1999b) for the locality type of Botucatu, State of São Paulo, Brazil, is geographically distributed only in cerrado formations (Napoli \& Caramaschi, 1999b) of São Paulo, Minas Gerais, and Mato Grosso do Sul states. In the State of São Paulo, this vegetation type occurs from the Botucatu boundaries to the north of the state. The species found in this area belongs to the group rubicundula ( $H$. tritaeniata complex) that was characterized by Napoli \& Caramaschi (1998, 1999a, 1999b, 2000) and includes the following species: Hyla rubicundula Reinhardt and Lütken, 1892; H. tritaeniata Bokermann, 1965; H. anataliasiasi Bokermann, 1972; H. araguaya Napoli \& Caramaschi, 1998; H. cerradensis Napoli \& Caramaschi, 1998; H. cachimbo Napoli \& Caramaschi, 1999a; H. jimi Napoli \& Caramaschi, 1999b; H. rhea, Napoli \& Caramaschi, 1999b; and H. elianeae, Napoli \& Caramaschi, 2000.

The species $H$. elianeae was described by Napoli \& Caramaschi (2000) from specimens collected in Bela Vista, Mato Grosso do Sul, Brazil. The geographical distribution of $H$. elianeae includes Goiás, Mato Grosso, Mato Grosso do Sul, and São Paulo states. A specimen was registered for Belo Horizonte, Minas Gerais, and the species can also occur in the Chaco area in Paraguay (Napoli \& Caramaschi, 2000).

Due to the lack of information on the characteristics of the advertisement calls of the species belonging to the group rubicundula, this work presents the descriptions of the advertisement calls and characteristics of vocalization behavior of $H$. $j i m i$, for the population in this locality type, and of $H$. elianeae, which until now have been unknown in the literature.

\section{MATERIALS AND METHODS}

Field observations and recordings were made in two open-area environments in Botucatu, São Paulo State: Environment I, a pond of $120 \times 50$ $\mathrm{m}$, located $\left(22^{\circ} 53^{\prime} 08^{\prime \prime} \mathrm{S}\right.$ and $\left.48^{\circ} 29^{\prime} 24^{\prime \prime} \mathrm{W}\right)$ at an $860 \mathrm{~m}$ altitude; Environment II: a pond of $100 \mathrm{x}$ $70 \mathrm{~m}$, located (22 $57^{\prime} 03^{\prime \prime} \mathrm{S}$ and $\left.48^{\circ} 27^{\prime} 36^{\prime \prime} \mathrm{W}\right)$ at an $810 \mathrm{~m}$ altitude. Jim (1980) considered this environment a headwaters swamp inside a cerrado formation. The two environments were characterized as large, permanent ponds, with continuous water renewal. The margins are swampy, with mainly herbaceous vegetation represented by Poaceae and Cyperaceae.

Field activities were carried out from August 1997 through June 1999. Visits occurred every fifteen days, starting from sunset (17:00) to the period of vocalization activity decrease (24:00 to $2: 30$ ).

Behavioral information was obtained using Martin \& Bateson's (1986) "focal animal" method, with sampling periods varying from one to 10 minutes, but reaching up to 30 minutes, mainly for observation of intra- and interspecific interactions.

The times when the vocalization activity began and when it peaked (chorus) were recorded, registering two moments: 1 ) individuals during the first 30 minutes after beginning vocalization activity (between 18:00 and 18:30), and 2) individuals in vocalization activities in chorus, at an average of two hours after beginning vocalization. At approximately one-hour intervals, the number of vocalizing males was estimated.

To study intraspecific interactions, individuals beginning vocalization activity were compared with the same ones during chorus vocalization and possible differences in the spectral and temporal structures were sought.

The vocalizations were recorded under field conditions with a digital (DAT) recorder (Sony TCD- 
D8) and an analog cassette recorder (Sony TCMS64V) coupled to external semidirectional (ME 66) and cardioid (ME 64) Sennheiser microphones. All recorded vocalizations were edited with a sampling rate of $44.100 \mathrm{~Hz}$ and 16 bits per sample in the mono-pattern.

The bioacoustic analyses were performed with a microcomputer using the program CoolEdit 96 (Syntryllium Software Corporation) with a 20.000 $\mathrm{Hz}$ sampling frequency. The 256-points option (FFT Fast Fourier Transform) and, when necessary, the 1024-points option was used, mainly in determining fundamental frequencies.

Nine traits of the advertisement call of both species were analyzed: frequency band, fundamental frequency (= dominant frequency; considered in this study as synonyms), pulse number per note, pulse duration, pulse repetition rate, note duration, note repetition rate, number of notes per sequence, and sequence duration. For the analyses and bioacoustics interpretations, the terms used follow Martins \& Jim (2003).

At the beginning and end of each field research period and at the beginning of every vocalization recording, air and water temperature were measured with a $0.5^{\circ} \mathrm{C}$ precision mercury thermometer. All the collected specimens had their snout-vent length (SVL) measured with a $0.01 \mathrm{~mm}$ precision caliper. The specimens whose calls were recorded were collected as voucher specimens and are in the Jorge Jim collection deposited in the Departamento de Zoologia, Instituto de Biociências, Universidade Estadual Paulista (UNESP), Botucatu, São Paulo, Brazil.

A Mann-Whitney rank sun test was used to compare intraspecific call traits (Ayres et al., 2000).

\section{RESULTS}

Males of $H$. jimi and $H$. elianeae presented the same seasonal periods of activities, with vocalization activities being registered between September and April for H. jimi, and September and March for H. elianeae. For both species, the largest densities of individuals vocalizing $(n>10)$ occurred between October and January.

Males of $H$. jimi and $H$. elianeae began call activities after sunset, between about 18:30 and 19:00 h. Call activity peak (chorus) for both species was registered at around 21:00 $\mathrm{h} \mathrm{(} \pm 30 \mathrm{~min}$.).

Vocalizations of 100 individuals (49 from $H$. jimi and 51 from H. elianeae) were obtained. Snout- vent length (SVL) of the males studied are showed as mean $\pm \mathrm{SD}$ (amplitude): H. jimi, $19.08 \pm 1.09$ $\mathrm{mm}(17.45-20.94 \mathrm{~mm})$; H. elianeae, $23.76 \pm 1.24$ $\mathrm{mm}(21.33-25.15 \mathrm{~mm})$

Advertisement call characteristics of the two species are summarized in Table 1.

Hyla Jimi Napoli \& Caramaschi (1999)

The vocalization of H. jimi (Fig. 1A-D) is composed of simple pulsed notes, emitted in consecutive series. The advertisement call presents frequencies that occupy the band between 3,000 to 4,900 $\mathrm{Hz}$. The fundamental frequency of the notes is between 3,600 to $4,600 \mathrm{~Hz}$. Energy concentration of the notes is around 3,900 to $4,000 \mathrm{~Hz}$ (Fig. 2A, B).

Two patterns of note emission were observed for males of $H$. jimi: one emitted by individuals in beginning vocalization activity or isolated from the aggregate, and another emitted by males interacting with closely neighboring males in chorus activities.

The males in beginning vocalization activities emit note sequences $\mathrm{s}$ with a duration of $4.5 \mathrm{~s}$ and an amplitude ranging from 1.2 to $6 \mathrm{~s}$. These series are composed of from 3 to 8 notes with a repetition rate of 1.6 notes per second (Fig. 1A, B). Each note has an average duration of $34 \mathrm{~ms}$, presenting from 3 to 6 pulses with durations that vary from 3 to 6 $\mathrm{ms}$ each. The rate of repetition of the pulses was of $11 \mathrm{~ms}$ with variation from 9 to $12 \mathrm{~ms}$. Energy concentration of the notes is around $3,900 \mathrm{~Hz}$ (Fig. 2A).

Males in vocalization activity in choruses emit a series of notes with duration of $2.9 \mathrm{~s}$, with width varying between 1.2 to $4.2 \mathrm{~s}$ (Fig. 1C-D). The series are constituted of from 4 to 12 repeated notes at a rate of 2.6 notes per second. The notes have a mean duration of $52 \mathrm{~ms}$, presenting 4 pulses on average with duration of between 3 and $6 \mathrm{~ms}$. The notes emitted during the chorus present pulses with a mean rate of repetition of $15 \mathrm{~ms}$, varying between 12 and $18 \mathrm{~ms}$. Frequently the first note of the series is lengthier, with 5 to 8 pulses (introductory notes) (Fig. 1C, D). Energy concentration of the notes is around $4,000 \mathrm{~Hz}$ (Fig. 2B).

A significant difference was verified in the temporal structure of the two vocalization patterns (vocalization beginning and chorus activity), durations of the series, number of notes emitted by series, rate of note repetition, durations of the notes, and repetition rates of the note pulses (Mann-Whitney rank sum test $\mathrm{p}<0.0001$ ). 
TABLE 1

Characteristics of nine variables of the advertisement calls of Hyla jimi and Hyla eliane in the beginning of vocalization activity and during chorus vocalization. Figures include mean \pm standard deviation, amplitude, and sample size.

\begin{tabular}{|c|c|c|c|}
\hline Variable & Note type & H. elianeae & H. jimi \\
\hline \multicolumn{2}{|l|}{ Frequency bands $(\mathrm{Hz})$} & $\begin{array}{l}2.400-4.380 \pm 140 \\
(2.350-4.470) n=679\end{array}$ & $\begin{array}{l}3.000-4.900 \pm 200 \\
(2.900-5.100) \mathrm{n}=576\end{array}$ \\
\hline \multicolumn{2}{|l|}{ Fundamental frequency $(\mathrm{Hz})$} & $2.900-4.000 \pm 200$ & $3.600-4.600 \pm 300$ \\
\hline \multirow[t]{2}{*}{ Number of pulses per note } & Initial call & $\begin{array}{l}3 \pm 1 \\
(2-5) n=93\end{array}$ & $\begin{array}{l}4 \pm 1 \\
(3-6) n=107\end{array}$ \\
\hline & Chorus & $\begin{array}{l}3 \pm 1 \\
(2-5) n=118\end{array}$ & $\begin{array}{l}4 \pm 2 \\
(3-9) n=75\end{array}$ \\
\hline \multirow[t]{2}{*}{ Pulse duration (ms) } & Initial call & $\begin{array}{l}3.48 \pm 0.84 \\
(2-6) n=93\end{array}$ & $\begin{array}{l}5.24 \pm 1.07 \\
(3-6) n=107\end{array}$ \\
\hline & Chorus & $\begin{array}{l}4.89 \pm 0.82 \\
(2-6) n=118\end{array}$ & $\begin{array}{l}5.97 \pm 1.04 \\
(3-6) n=75\end{array}$ \\
\hline \multirow[t]{2}{*}{ Pulse repetition rate (ms) } & Initial call & $\begin{array}{l}4.52 \pm 0.71 \\
(3-6) n=93\end{array}$ & $\begin{array}{l}11.37 \pm 0.96 \\
(9-12) \mathrm{n}=107\end{array}$ \\
\hline & Chorus & $\begin{array}{l}4.89 \pm 0.82 \\
(3-6) n=126\end{array}$ & $\begin{array}{l}15.57 \pm 1.23 \\
(12-18) \mathrm{n}=152\end{array}$ \\
\hline \multirow[t]{2}{*}{ Note duration (ms) } & Initial call & $\begin{array}{l}18.56 \pm 2.76 \\
(14-26) n=111\end{array}$ & $\begin{array}{l}34 \pm 7 \\
(26-47) n=101\end{array}$ \\
\hline & Chorus & $\begin{array}{l}17.95 \pm 2.91 \\
(14-26) n=214\end{array}$ & $\begin{array}{l}52.4 \pm 9.6 \\
(37-72) n=106 \\
\end{array}$ \\
\hline \multirow[t]{2}{*}{$\begin{array}{l}\text { Note repetition rate } \\
\text { (note/sec.) }\end{array}$} & Initial call & $\begin{array}{l}1.32 \pm 0.30 \\
(0.72-1.88) \mathrm{n}=102\end{array}$ & $\begin{array}{l}1.6 \pm 0.29 \\
(0.92-1.98) \mathrm{n}=96\end{array}$ \\
\hline & Chorus & $\begin{array}{l}3.12 \pm 0.45 \\
(2.6-4.02) \mathrm{n}=207\end{array}$ & $\begin{array}{c}2.64 \pm 0,51 \\
(2.01-4.93) \mathrm{n}=123\end{array}$ \\
\hline \multirow{2}{*}{$\begin{array}{l}\text { Number of notes per } \\
\text { sequence }\end{array}$} & Initial call & $14.82 \pm 16.06(4-86) n=43$ & $5.5 \pm 2.6(3-8) n=31$ \\
\hline & Chorus & $12.36 \pm 8.86(5-65) n=38$ & $8.56 \pm 1.9(4-12) n=48$ \\
\hline \multirow[t]{2}{*}{ Sequence duration (sec.) } & Initial call & $\begin{array}{l}12.69 \pm 10.6 \\
(2.9-61.24) \mathrm{n}=43\end{array}$ & $\begin{array}{l}4.56 \pm 1.37 \\
(1.24-6.09) \mathrm{n}=31\end{array}$ \\
\hline & Chorus & $\begin{array}{l}5.82 \pm 6.72 \\
(1.42-25.29) \mathrm{n}=38\end{array}$ & $\begin{array}{l}2.92 \pm 0,758 \\
(1.24-4.26) \mathrm{n}=48\end{array}$ \\
\hline
\end{tabular}

Hyla elianeae Napoli \& Caramaschi (2000)

The advertisement call of $H$. elianeae (Fig. $3 \mathrm{~A}-\mathrm{D})$ is composed of simple notes, with the emission rhythm presenting fairly irregular and varied intervals, and constituted by isolated notes or in series.

The notes present a frequency band between 2,400 and $4,380 \mathrm{~Hz}$, with width between 2,350 and $4,470 \mathrm{~Hz}$. The fundamental frequency of the no- tes is between 2,900 and 4,000 Hz. The largest energy concentration of the notes is around 3,200 to $3,300 \mathrm{~Hz}$ (Fig. 4A, B).

The notes of the advertisement call presented a mean duration of $18 \mathrm{~ms}$, containing from 2 to 5 similar pulses, each pulse having a mean duration of $4 \mathrm{~ms}$ with width amplitude varying between from 2 to $6 \mathrm{~ms}$ and mean pulse repetition rate of $4.5 \mathrm{~ms}$ (Table 1). 

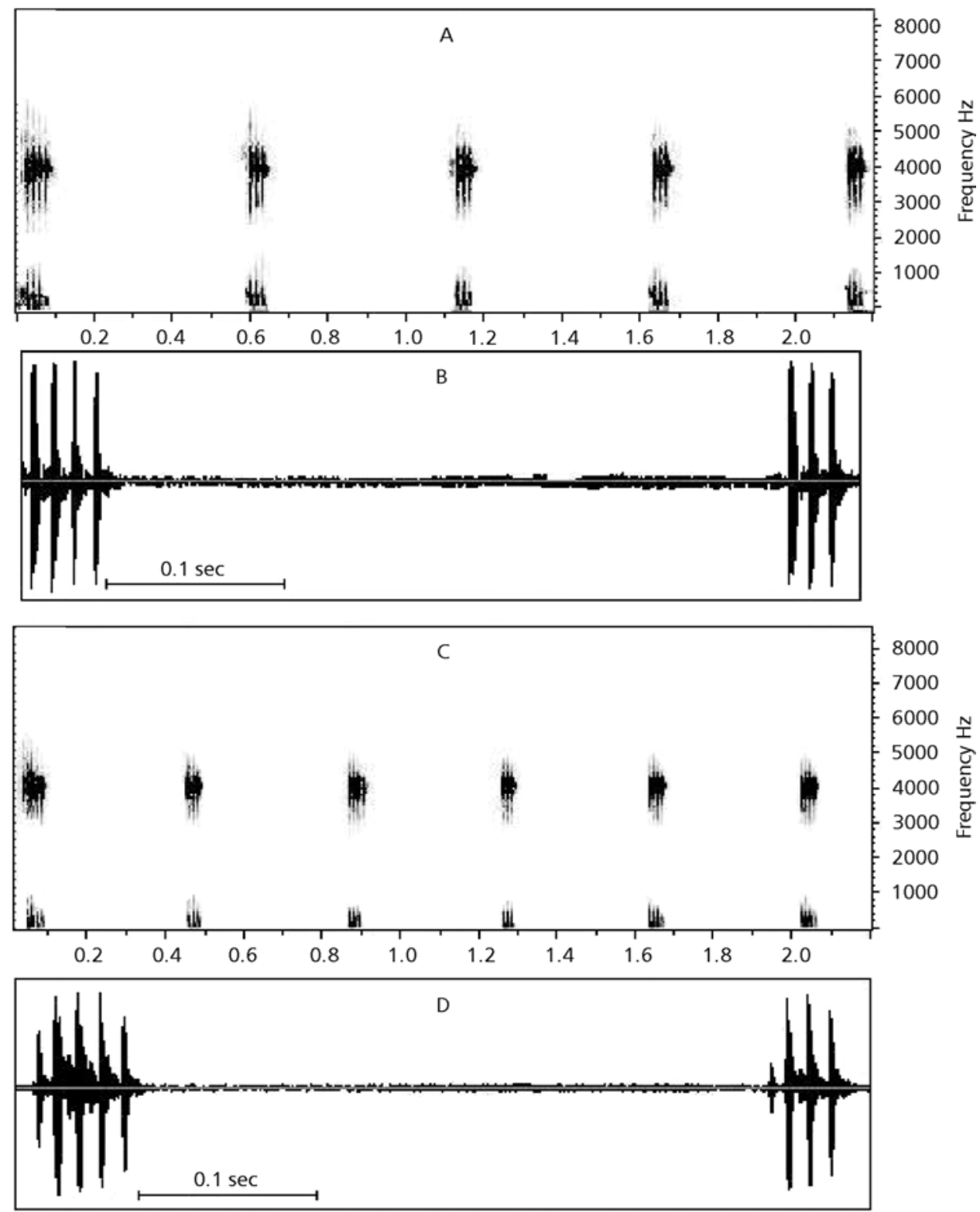

Fig. 1 - Advertisement call of Hyla jimi. Sonogram (A) and oscillogram (B) of the first note in beginning activity. Air temperature $17^{\circ} \mathrm{C}$. Sonogram (C) and oscillogram (D) of call during chorus activity. Air temperature $20^{\circ} \mathrm{C}$.

The number of notes emitted by sequence and the sequence duration were extremely variable. On $11 / 26 / 1998$, an exemplar of $H$. elianeae was registered emitting a series containing 104 notes with a total duration of $61.2 \mathrm{~s}$; soon afterwards it emitted another series of 23 notes with a $21.6 \mathrm{~s}$ duration and a 6- note series with a $9.3 \mathrm{~s}$ duration. These 3 series were interrupted by silent pauses of 1.7, 2.6, and $4.1 \mathrm{~s}$, respectively. The note emission rhythms varied greatly among other series (mean \pm
$\mathrm{SD}=0.748 \pm 0.146 \mathrm{~s} ;$ amplitude $=0.526-1.609 \mathrm{~s}$; $\mathrm{n}=126)$.

There was a significant difference between the number of emitted notes and also among the duration of the series (Mann-Whitney rank sum test $\mathrm{p}<0.0001$ ) in relation to the notes emitted in vocalization activity beginning and vocalization in chorus.

Isolated specimens or those beginning activities emit with repetition rates averaging 1.32 notes per second, with variation ranging between 
0.72 to $188 \mathrm{~s}$ (Table 1$)$. In chorus activities, the individuals emit series of notes with a repetition rate varying between 2 to 4 notes a second. These vocalizations are composed by a number of varied notes and the final notes of the sequence have a fast repetition rate of between 177 to $375 \mathrm{~ms}$.

Significant differences existed in note repetition rates (Mann-Whitney rank sum test $\mathrm{p}<$ $0.0001)$ between vocalization in isolated individuals (or beginning activities) and that in chorus activities.

\section{DISCUSSION}

The advertisement call of frog species may be a single note, a series of identical notes, a complex combination of one or more notes, or note groups with different acoustic properties. These call types are common in most hylids (Duellman, 1970).

The advertisement call of the species studied here consists in the emission of consecutive series of simple notes with relatively fast repetition rates. The vocalization behavior of both species is associated to different moments in social organization. At the beginning of vocalization activity or in that of isolated individuals, emission rate is lower. During chorus activity, on the other hand, both rates and note number per series are higher. This vocalization behavior variation is related to the presence of other vocalizing males in the vicinity. The same patterns were observed in Hyla ebraccata, H. phlebodes, and H. microcephala by Schwartz \& Wells (1984b, 1985), Wells \& Schwartz (1984), and Wells (1988).

Wells \& Taigen (1986) observed $H$. versicolor males altering their call behavior in response to changes in social organization of the aggregate. According to these authors, males spend little energy in vocalization when few males are present, but increase vocalization efforts when competition among males is intense. In the species studied by us, this change was marked by increasing note emission rates during chorus activity.

The difference in rhythm before and during chorus activity demonstrates that these behavioral moments are important in social organization and that this fact must be considered in bioacoustics analysis, principally in studies on anuran systematics. The importance of these behavioral interactions has been emphasized by Sullivan (1983) and Wells (1988), mainly for mate choice by the female, who uses the characteristics of the male call or calling behavior to assess differences in the "genetic quality" of males or in body size that may provide reproduction benefits.

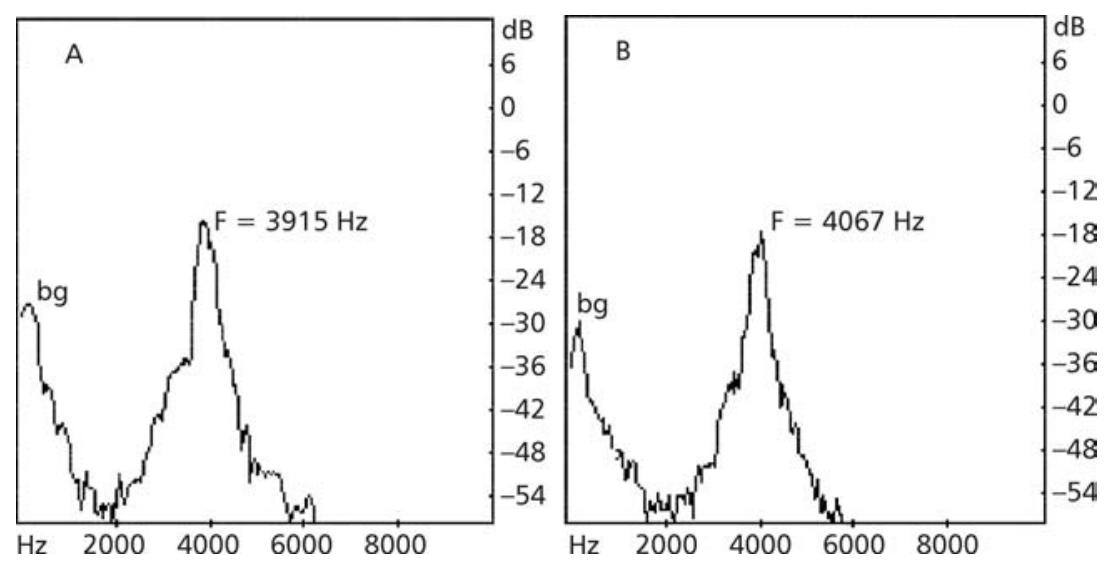

Fig. 2 - Advertisement call of Hyla jimi: power spectrum showing frequency bands and note intensity. Energy concentration of around 3,900 to $4,000 \mathrm{~Hz}$. (A) Notes in beginning activity and (B) during chorus activity (bg = background; $\mathrm{F}=$ fundamental frequency). 

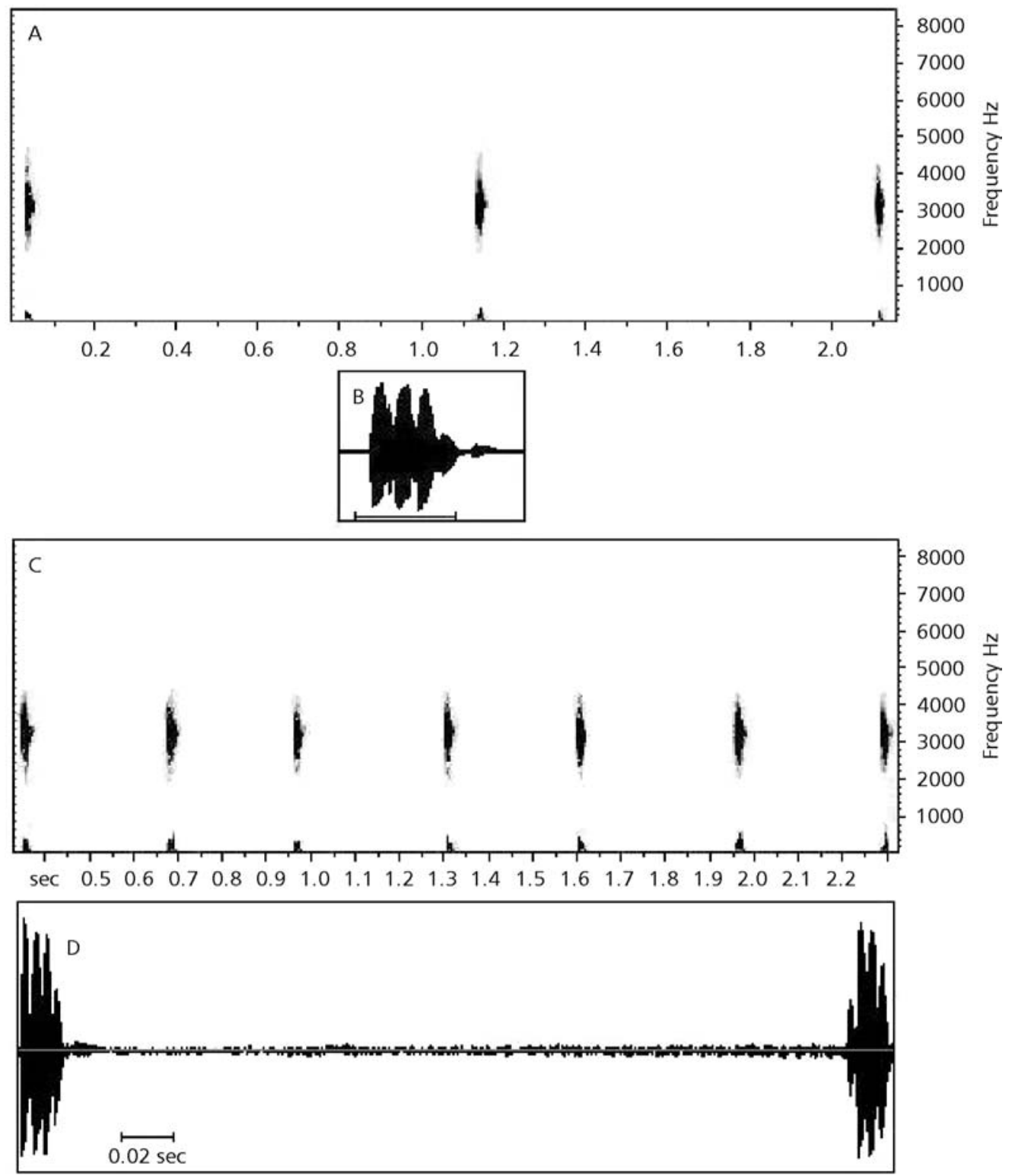

Fig. 3 - Advertisement call of Hyla elianeae. Sonogram (A) and oscillogram (B) of call segment at vocalization activity beginning. Air temperature: $22^{\circ} \mathrm{C}$. Sonogram (C) and oscillogram (D) during chorus activity. Air temperature: $21^{\circ} \mathrm{C}$.

In relation to species of the group rubicundula, little work had been done on acoustic characteristics. Cardoso \& Vielliard (1985), in analyzing the bioacustical characteristics of the population in a typical locality for H. rubicundula (Lagoa Santa, Minas Gerais), described an advertisement call with notes emitted between 2.7 and $4.4 \mathrm{kHz}$, presenting fairly varied rhythms, in $0.3 \mathrm{~s}$ intervals. The notes presented a $0.02 \mathrm{~s}$ duration and contained from 3 to
4 equal pulses. The temporal and spectral parameters described by Cardoso \& Vielliard (1985) were very similar to those obtained for $H$. elianeae in Botucatu, SP. The vocalization of $H$. elianeae presented a wider frequency band (amplitude $=2.350-4.470 \mathrm{~Hz}$ ), this being the only difference verified between the vocalizations of the two species.

According to Cardoso \& Vielliard (1985), the variations verified in the note emission rhythm in 
H. rubicundula demonstrate that a larger number of analyses, of considerable duration and in different behavioral situations, are fundamental in defining the functional vocalization parameters of a certain population. For the population of H. elianeae, recordings were done along a two-year period, with registration of a great number of note sequences in different activity periods. There were differences in emission rhythms of the individuals' notes in beginning vocalization activity and in chorus. The calling behavior described by Cardoso \& Vielliard (1985) for $H$. rubicundula is very similar to that of $H$. elianeae described here.

Haddad et al. (1988), in studying the amphibian anurans of the Parque Nacional da Serra da Canastra, Minas Gerais, described H. elongata [a junior synonym of $H$. rubicundula, Bokermann (1968)], with based on acoustic characteristics (structures of the pulses) present in the advertisement call in the two species. The species referred to as H. elongata by Haddad et al. (1988), presents a call with notes containing 3 transitory pulses, with none overlapping, and occupying the frequency band between 3.5 and $4.5 \mathrm{kHz}$ or from 3.9 to $4.9 \mathrm{kHz}$. According to Haddad et al. (1988), the main differences between the vocalizations of $H$. elongata and H. rubicundula relate to note structure, with no pulses juxtaposed in H. elongata whereas such are present in $H$. rubicundula. The advertisement call of $H$. elianeae presents notes with 2 to 5 similar and frequently juxtaposed pulses.

Napoli \& Caramaschi (1999a) recorded vocalization of $H$. rubicundula (denominated as the morphospecies "Pseudorubicundula") from Silvânia, Goiás State. The advertisement call presents a frequency band between 3.5 and $4.8 \mathrm{kHz}$; the notes, composed of from 3 to 4 non-juxtaposed pulses present durations of from 0.03 to $0.04 \mathrm{~s}$. These authors mention that comparisons between the advertisement call of H. rubicundula (Cardoso \& Vielliard, 1985) and the call of the morph-species of Goiás revealed great similarities and that both belong to $H$. rubicundula. The sonogram analysis and the data presented in the work of Napoli \& Caramaschi (1999a) differ from the data here obtained for the topotypic population of $H$. elianeae.

The acoustic characteristics of the population of $H$. elianeae here studied are fairly similar to those already described for $H$. rubicundula, showing that this group of species requires further studies involving other characters, e.g., tadpoles, reproductive behavior, bioacoustics, and molecular analysis, to better elucidate the taxonomic status of the group rubicundula.
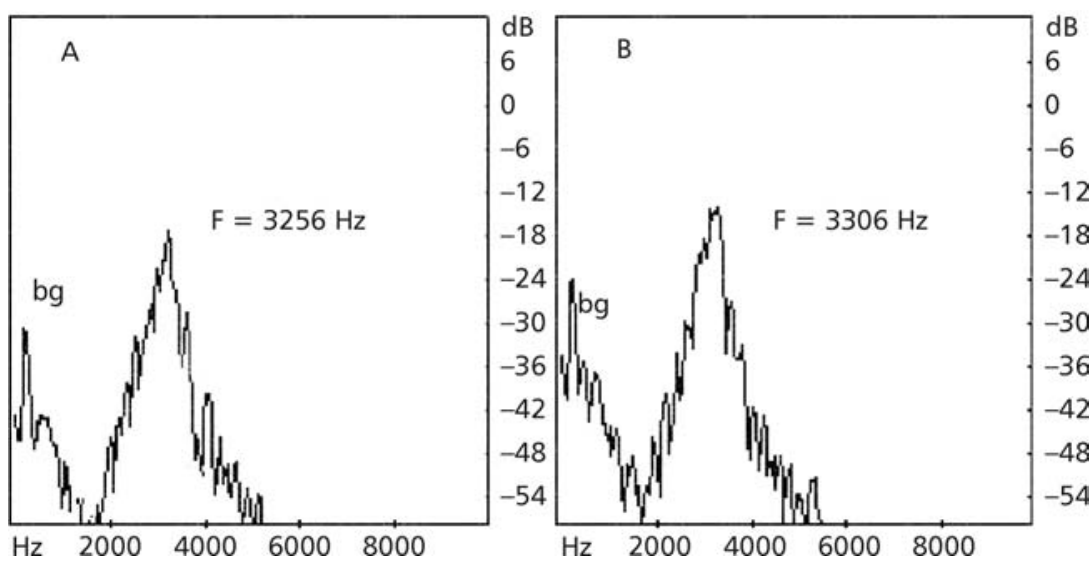

Fig. 4 - Advertisement call of Hyla elianeae: power spectrum (A) notes in beginning activity, with intensity and energy concentration of around $3200 \mathrm{~Hz}$ and (B) during chorus activity, with energy concentration around 3,300 $\mathrm{Hz}$ (bg = background; $\mathrm{F}=$ fundamental frequency). 
Acknowledgements - We thank Dr. Jacques M. E. Vielliard for his valuable suggestions and guidance. We are grateful to Dr. Célio F. B. Haddad for his suggestions and corrections. We also express thanks to Dra. Elieth F. Spirandeli Cruz, Dra. Rosangela A. Marques, Dr. Benedito R. Cardana, and MSc. Sílvio Cesar Almeida for providing valuable comments and help in field work. We are grateful to Dra. Maria Helena de A. Leme for statistical support. We are grateful to Sr. Nelson Carneiro for his most valuable assistance in field work. The first author thanks the Universidade de Taubaté (UNITAU) for providing financial support (process n. BIO - 159/97 - PRPPG).

\section{REFERENCES}

AYRES, M., AYRES, JR. M., AYRES, D. L. \& SANTOS, A S., 2000, BioEstat 2.0: aplicações estatísticas nas áreas das ciências biológicas e médicas. Sociedade Civil Mamirauá, CNPq, Brasília, 259p.

BASTOS, R. F. \& HADDAD, C. F. B., 1995, Vocalizações e interações acústicas em $H$. elegans (Anura, Hylidae) durante a atividade reprodutiva. Naturalia, 20: 165-176.

BOKERMANN, W. A. C., 1968, Notas sobre alguns anfíbios brasileiros descritos por Reinhardt \& Lütken em 1862 (Amphibia). Rev. Brasil. Biol., 28(3): 327-329.

CARDOSO, A. J. \& VIELLIARD, J. M. E., 1985, Caracterização bioacústica da população topotípica de Hyla rubicundula (Amphibia, Anura). Revta. Bras. Zool., 2(7): 423-426.

DUELLMANN, W. E., 1970, The hylidae frogs of Middle America. Monogr. Mus. Nat. Hist. Univ. Kansas, (1): 1-753.

GARCIA, P. C. A., VINCIPROVA, G. \& HADDAD, C. F. B. 2001, Vocalização, girinos, distribuição geográfica e novos comentários sobre Hyla marginata Boulenger, 1887 (Anura, Hylidae, Hylinae). Bol. Mus. Nac., N. S., Zool., 460: 1-19.

GIVEN, M. F., 1999, Frequency alteration of the advertisement call in the carpenter frog, Rana virgatipes. Herpetologica, 55(3): 304-317.

GRAFE, T. U., 1996, The function of call alternation in the African reed frog (Hyperolius marmoratus): precise call timing prevents auditory masking. Behav. Ecol. Sociobiol., 38: $149-158$

HADDAD, C. F. B., ANDRADE, G. V. \& CARDOSO, A. J., 1988 Anfíbios anuros no parque Nacional da Serra da Canastra, Estado de Minas Gerais. Brasil Florestal, 64: 9-20.

HARTMANN, M. T., HARTMANN, P. A. \& HADDAD, C. F. B., 2002, Advertisement calls of Chiasmocleis carvalhoi, Chiasmocleis mehelyi, and Myersiella micropd (Microhylidae). J. Herpetol., 36(3): 509-511.

JIM, J., 1980, Aspectos ecológicos dos anfibios registrados na região de Botucatu, São Paulo (Amphibia, Anura). Tese de Doutorado, IB-USP, Universidade de São Paulo, São Paulo, 332p.

MÁRQUEZ, R., DE LA RIVA, I. \& BOSCH, J., 1993 , Advertisement call of Bolivian species of Hyla (Amphibia, Anura, Hylidae). Biotropica, 25(4): 426-443.

MARTIN, P. \& BATESON, P., 1986, Measuring behaviour an introductory guide. Univ. Press, Cambridge, 199p.
MARTINS, I. A. \& JIM, J., 2003, Bioacoustic analysis of advertisement call in Hyla nana and Hyla sanborni (Anura, Hylidae) in Botucatu, São Paulo, Brazil. Braz. J. Biol., 64(3): 507-516.

NAPOLI, M. F. \& CARAMASCHI, U., 1998, Duas novas espécies de Hyla Laurenti, 1768 do Brasil Central afins de H. tritaeniata Bokermann, 1965 (Amphibia, Anura, Hylidae). Bol. Mus. Nac., N. S., Zool., 391: 1-12.

NAPOLI, M. F. \& CARAMASCHI, U., 1999a, Geographic variation of Hyla rubicundula and Hyla anataliasiasi, with the description of a new species (Anura, Hylidae). Alytes, 16(3-4): 165-189.

NAPOLI, M. F. \& CARAMASCHI, U., 1999b, Variation and description of two new Brazilian Hyla of the H. tritaeniata complex (Amphibia, Anura, Hylidae). Bol. Mus. Nac., N. S., Zool., 407: 1-11.

NAPOLI, M. F. \& CARAMASCHI, U., 2000, Description and variation of a new Brazilian species of the Hyla rubicundula group (Anura, Hylidae). Alytes, 17(3-4): 165-184.

PASSMORE, N. I., 1981, The relevance of the specific mate recognition concept to anuran reproductive biology. Monitore Zool. Ital., 6: 93-108.

POMBAL, J. P. JR., BASTOS, R. P. \& HADDAD, C. F. B., 1995 , Vocalizações de algumas espécies do gênero Scinax (Anura, Hylidae) do sudeste do Brasil e comentários taxonômicos. Naturália, 20: 213-225.

ROSSA-FERES, D. C. \& JIM, J., 2001, Similaridade do sítio de vocalização em uma comunidade de Anfíbios anuros da região Noroeste do Estado de São Paulo, Brasil. Revta. Bras. Zool., 18(2): 439-454.

RYAN, M. J., 1985, The túngara frog: a study in sexual selection and communication. University of Chicago Press, Chicago, $230 \mathrm{p}$.

RYAN, M. J., 2001, Anuran communication. Smithsonian Institution Press, Washington, London, 252p.

SALTHE, S. N. \& MECHAM, J. S., 1974, Reproductive and courtship patterns, pp. 309-521. In: B. Lofts (ed.), Physiology of the Amphibia. Academic Press, New York.

SCHWARTZ, J. J. \& WELLS, K. D., 1983, An experimental study of acoustic interference between two species of neotropical treefrogs. Anim. Behav., 31: 181-190.

SCHWARTZ, J. J. \& WELLS, K. D., 1984a, Interspecific acoustic interactions of the neotropical treefrog Hyla ebraccata. Behav. Ecol. Sociobiol., 14: 211-224.

SCHWARTZ, J. J. \& WELLS, K. D., 1984b, Vocal behavior of the neotropical treefrog Hyla phlebodes. Herpetologica, 40: 452-463.

SCHWARTZ, J. J. \& WELLS, K. D., 1985, Intra- and interspecific vocal behavior of the neotropical treefrog Hyla microcephala. Copeia, 1985: 27-38.

SULLIVAN, B. K., 1983, Sexual selection in Woodhouse's (Bufo woodhousei) II. Female choice. Anim. Behav., 31: 10111017.

WELLS, K. D., 1977, The social behaviour of anuran amphibians. Anim. Behav., 25: 666-693. 
WELLS, K. D., 1988, The effect of social interations on anuran vocal behavior, pp. 433-454. In: B. Fritzsch, M. J. Ryan, W. Wilczynski, T. E. Hetherington \& W. Walkowiak (eds.), The evolution of amphibian auditory systems. John Wiley and Sons, New York.

WELLS, K. D. \& SCHWARTZ, J. J., 1984, Vocal communication in a neotropical treefrog, Hyla ebraccata: advertisement calls. Anim. Behav., 32: 405-420.
WELLS, K. D. \& TAIGEN, T. L., 1986, The effect of social interactions on calling energetics in the gray treefrog (Hyla versicolor). Behav. Ecol. Sociobiol., 19: 9-18. 